\title{
CELERY HERB ESSENTIAL OIL IN THE FORMULATION OF ANTIDANDRUFF HAIR TONIC AGAINST PITYROSPORUM OVALE
}

\author{
Riska Surya Ningrum ${ }^{1}$, Antonius Budi Prasetyo ${ }^{2}$, Alfinda Novi Kristanti ${ }^{2 *}$ \\ ${ }^{1}$ Student of Undergraduate Chemistry Study Program, Faculty of Science and Technology \\ ${ }^{2}$ Department of Chemistry, Faculty of Science and Technology \\ Universitas Airlangga \\ *email: alfinda-n-k@fst.unair.ac.id
}

Received 16 Oktober 2017

Accepted 28 Nopember 2017

\begin{abstract}
Essential oil from Apium graveolens (celery), a species belonged to Apiceae, was isolated, identified, and tested its activity against fungi Pityrosporum ovale, fungi that cause dandruff problem. Essential oil isolation was conducted by steam distillation. The identification with GC-MS showed that the major compound of celery essential oil was 3-isobutylidenphalide. The anti-fungal activity test was performed using pure celery oil and celery oil added with virgin coconut oil (VCO) and paraffin oil that are usually used as components in hair tonic formulation. The bioactivity test showed that celery oil, whether in pure form or in hair tonic formulation exhibited excellent growth inhibition activity of Pityrosporum ovale
\end{abstract}

Keywords: essential oil, celery, Apium graveolens, Pityrosporum ovale

\section{Introduction}

Celery belongs to Apiaceae, is aromatic herb growing on lowland or highland, and is well known of its essential oil. According to the history, celery has been used as a vegetable since 1640, but it was only recognized as a medicinal plant in 1942. As a medicinal plant, celery is able to stimulate digestive enzymes in increasing the appetite, use as diuretic agent, to maintain blood vessel flexibility, to lower blood pressure and wide peripheral blood vessels (Sudarsono, 1996). A study showed that celery can used as hypocholesterolemia and hypolipidemia agents even though the dosages used in that study not decrease the total cholesterol and lipid significantly (Juheini, 2002). In addition, celery is also efficacious to nourish hair. The juice of celery herb showed an activity in promoting hair growth and increasing hair thickness (Kuncari, 2015). Previous studies mentioned that the ethanol extract of celery herb showed inhibitory activity against
Pityrosporum ovale, a fungi causing dandruff (Sukandar, 2006), Streptococcus mutans, the most important bacteria in the process of dental caries (Majidah, 2014), and Candida albicans, one microorganism that causes candidiasis (Rachmawati, 2014). Meanwhile, the essential oils of celery can inhibit the growth of Staphylococcus aureus, Listeria monocytogenes and L. ivanovii (Misic, 2008).

In this study we tested the antifungal activity of the essential oil of celery against Pityrosporum ovale, a fungus that causes dandruff. This fungus is a naturally occurring yeast-like organism found on the scalp and other parts of human skin. It's mostly found on skin areas with plenty of sebaceous glands, such as on scalp, face, and upper part of the body (Niharika, 2010). Several synthetic fungicide have been produced to fight dandruff problems, besides the herbal ingredients which assumed to have good anti-dandruff activity. This research is a study on the 
efficacy of anti-dandruff substances from herbal origin, in this case was celery essential oil, in the formulation of antidandruff hair tonic against Pityrosporum ovale in vitro. The celery essential oil was also used due to expectation of its flavor properties. Ketoconazole was used as positive control due to its best known of anti-Pityrosporum activity (Prabhamanju, 2009).

\section{Materials and Methods}

Equipment and materials

Celery herbs were procured from the local market of Surabaya, East-Java, as well as ketoconazole. Pityrosporum ovale was cultured in the dermatitis laboratory of local hospital. The chemicals used in this study were n-hexane, $\mathrm{CaCl}_{2}$ anhydrous, distilled water and the media Sabouraud Dextrose Agar (SDA) for fungus. Apparatus and instrument used in this study was a set of steam distillation and GC-MS GC2010 MSQP 2010S Shimadzu.

\section{Research procedure}

Isolation and identification of celery essential oil

The celery essential oil was obtained by steam distillation from celery herbs (Apium graveolens L.) which were first cleaned and cut into small pieces. The essential oil obtained was placed in a dark glass bottle, closed tightly, and stored in a refrigerator. Furthermore, celery essential oil was analyzed using GC-MS

\section{Preparation of fungus}

Pityrosporum ovale was taken from seborrhoeic dermatitis patient and then was cultured on agar SDA (Sabouraund Dextrose Agar) media wich was contained $20 \mathrm{~g}$ of glucose, $5 \mathrm{~g}$ of pepton, and $9 \mathrm{~g}$ of agar. The final volume of medium was adjusted to $500 \mathrm{~mL}$ by adding aquades (Funder, 1968). Preparation of inoculum was done in this way. Sterilized water (10 $\mathrm{mL}$ ) was added to P.ovale stock culture and then was shaked with vortex. OD was measured using Spectrophotometer at 425 $\mathrm{nm}$ to get 0.45 . This suspension would be used to activity test (Khan, 1992).

Determination of Antifungal properties of celery essential oil

Various concentration of celery essential oil $(2 \mathrm{~mL}, 4 \mathrm{~mL}, 6 \mathrm{~mL}, 8 \mathrm{~mL}, 10$ $\mathrm{mL}$ ) were prepared. Ten $\mathrm{ml}$ of VCO and $2.5 \mathrm{ml}$ of parrafin liquid were added into each concentration. The inhibiting capacity of each concentration of essential oil was tested using agar disc method. The control positive using for this test was a solution of ketoconazole $2 \%(\mathrm{w} / \mathrm{w})$. As comparative, the anti-pytyrosporum of pure essential oil experiment was also conducted.

Twenty ml of SDA media which had been diluted was mixed with $1 \mathrm{~mL}$ of inoculum and then poured in a petri dish, and allowed to solid. Three sterile paper discs were placed on agar medium in a petri dish. Thirty $\mathrm{ml}$ of each test solution was added to the disc paper drop wise. Each petri dish was incubated for 3-4 days at $25{ }^{\circ} \mathrm{C}$. Growth inhibition around the paper discs was measured. The experiment was conducted in triplicate

\section{Results and Discussion}

The yield of celery essential oil obtained from steam distillation process was $0,13 \%$. The analysis by GC-MS showed that the main component of this essential oil was $\beta$-selinene (time retention $22.025, \%$ Area 0.77) and 3isobutylidenphthalide (time retention 25.933, \% Area 30.16). The structure and the mass spectrum of these compounds are described in Figure 1 and Figure 2 respectively. This result differed from those published before, which stated that limonene was the major constituent of Apium graveolens essential oil (Van Wassenhove, 1990; Hassanen, 2015). However, it has been said that terpenes and phtalides are the key volatile components found in various cultivars of celery (van Wassenhove, 1990). Comparison result of antifungal activity between celery 
essential oil and ketoconazole against $P$. ovale are presented in the Table 1 . The activity test of pure essential oils and ketokenazol $2 \%$ indicates that diameter of inhibition was $16.7 \mathrm{~cm}$ and $25.7 \mathrm{~cm}$ respectively. From this result showed that celery oil exhibited an antifungal activity against $P$. ovale. However, its activity is lower than ketokenazole Thus, celery essential oil showed as alternative herbal substance to be used in the formulation of anti-dandruff hair tonic. Furthermore, the anti-fungal activity test of celery essential oil mixed with VCO and paraffin liquid as usually found in hair tonic formulations was done. The result of the bioactivity test was displayed in Table 2<smiles>C=C(C)C1CCC2(C)CCCC(=C)C2C1</smiles><smiles>CC(C)/C=C1\OC(=O)c2ccccc21</smiles>

Figure 1. The structure of main compounds in celery oil

Hit\#:1 Entry:70939 Library:WILEY229.LIB

SI:93 Formula:C15 H24 CAS:17066-67-0 MolWeight:204 RetIndex:0

CompName:.beta.-Selinene \$ Naphthalene, decahydro-4a-methyl-1-methylene-7-(1-methylethenyl)-, [4aR-(4a.alpha.,7.alpha.,8a.br

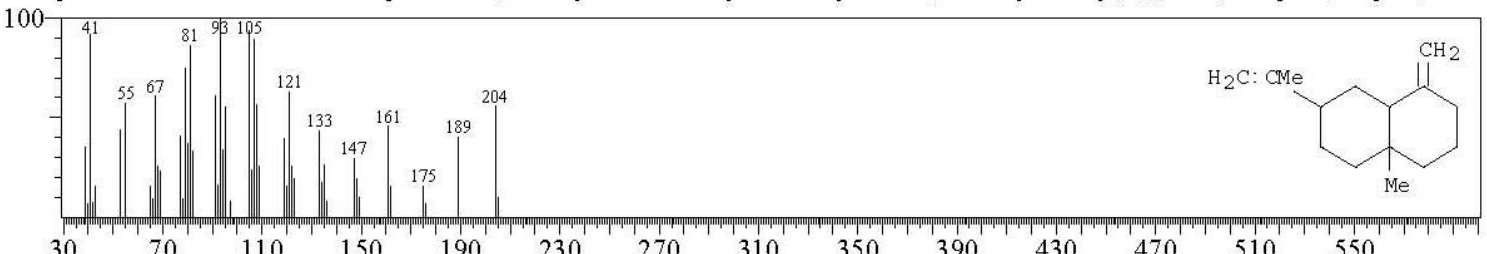

Hit\#:1 Entry:57372 Library:WILEY229.LIB

SI:94 Formula:C12 H12 O2 CAS:0-0-0 MolWeight:188 RetIndex:0

CompName:3-Isobutylidenphthalide \$\$

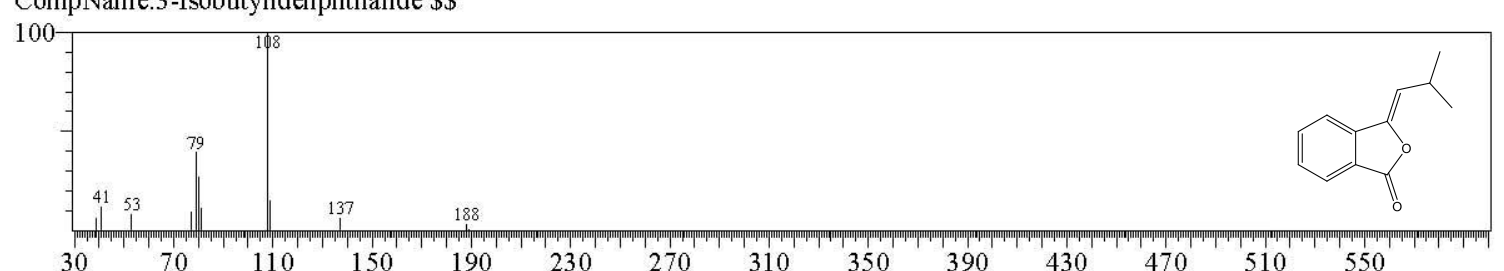

Figure 2. Mass spectrums of main compounds

Table 1. Antifungal activity of celery essential oil and ketoconazole

\begin{tabular}{ccccc} 
Sample & \multicolumn{4}{c}{ Diameter (mm) } \\
& $\mathbf{1}$ & $\mathbf{2}$ & $\mathbf{3}$ & Average \\
\hline 1 mL essential oil & 9 & 24 & 17 & 16.7 \\
Ketokenazole 2\% & 19 & 23 & 35 & 25.7 \\
\hline
\end{tabular}


Table 2. Bioactivity test result of sample (celery essential oil in various concentrations mixed with VCO and paraffin liquid)

\begin{tabular}{cccccccc}
\hline No. & $\begin{array}{c}\text { Essential oil } \\
(\mathbf{m L})\end{array}$ & $\begin{array}{c}\text { VCO } \\
(\mathbf{m L})\end{array}$ & $\begin{array}{c}\text { Parafin Liquid } \\
(\mathbf{m L})\end{array}$ & \multicolumn{4}{c}{ Diameter (cm) } \\
& & & & $\mathbf{1}$ & $\mathbf{2}$ & $\mathbf{3}$ & Average \\
\hline 1 & 0 & 10 & 2,5 & 0 & 0 & 0 & 0 \\
2 & 2 & 10 & 2,5 & 0 & 0 & 0 & 0 \\
3 & 4 & 10 & 2,5 & 0 & 0 & 0 & 0 \\
4 & 6 & 10 & 2,5 & 1,8 & 0,9 & 0 & 0,9 \\
5 & 8 & 10 & 2,5 & 1,7 & 0,6 & 1,6 & 1,3 \\
6 & 10 & 10 & 2,5 & 2,0 & 0,9 & 1,5 & 1,47 \\
\hline
\end{tabular}

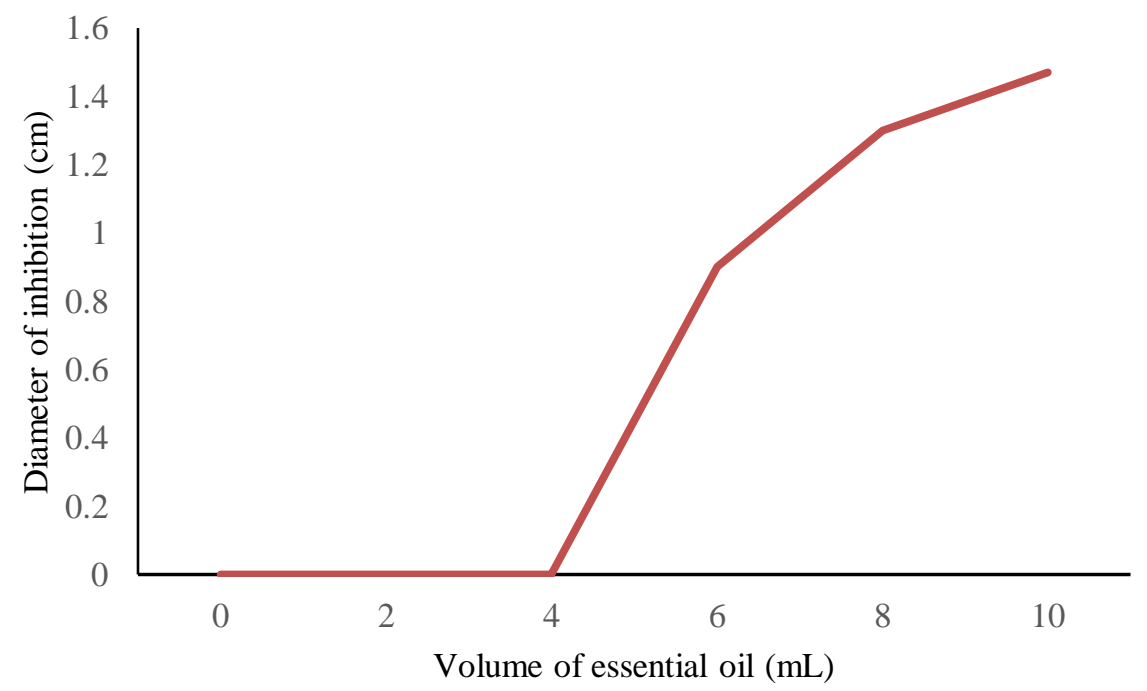

Figure 3. Curve of the relationship between the concentration of celery oil in hair tonic with diameter of growth inhibition of P.ovale

At a concentration of 2 and $4 \mathrm{~mL}$ of essential oil, no anti-fungal activity was observed. The anti-fungal activity was observed started from the concentration of 6,8 , and $10 \mathrm{ml}$, whereas the mixture of VCO with liquid paraffin (no essential oil) did not exhibit anti-fungal activity.

\section{References}

Funder, S., 1968, Practical Micology Manual For Identification Of Fungi, Hafner Publishing Company Inc., New York, USA

\section{Conclusion}

Based on the result, it can be stated that the essential oil of celery may inhibit the growth of Pityrosporum ovale. Therefore, the use of this essential oil as an ingredient in hair tonic or anti-dandruff shampoo formulation can be recommended. In addition, it can also serve as a fragrance.

Hassanen, N.H.M.; Eissa, A.M.F.; Hafez, S.A.M.; Mosa, E.A.M. 2015. Antioxidant and antimicrobial activity of celery (Apium graveolens) and coriander (Coriandrum sativum) herb and seed essential oil. International Journal Current Microbiology and Applied Sciences, 4(3), 284-296 
Juheini. 2002. Pemanfaatan herba seledri (Apium graveolens L.) untuk menurunkan kolesterol dan lipid dalam darah tikus putih yang diberi diit tinggi kolesterol dan lemak. Makara, Sains, 6(2), 65-69

Khan, M.Y.; Dahot, M.U.; Khan, M.Y. 1992. Single cell protein production by Penicillium javanicum from pretreated rice husk, Journal of Islamic Academy of Sciences, 5(1), 39-43.

Kuncari, E.S.; Iskandarsyah; Praptiwi. 2015. The irritation and hair growth activity test of male S-D mice : Effect of gel containing apigenin and celery (Apium graveolens L.) juice, Media Litbangkes, 25(1), 15-22

Majidah, D.; Fatmawati, D.W.A.; Gunadi, A. 2014. Antibacterial activity of celery leaves extract (Apium graveolens L.) against Streptococcus mutans as an alternative mouthwash, Artikel ilmiah hasil penelitian mahasiswa, Universitas Jember

Misic, D.; Zizovic, I.; Stamenic, M.; Asanin, R.; Ristic, M.; Petrovic, S.D.; Skala, D. 2008. Antimicrobial activity of celery fruit isolates and SFE process modeling, Biochemical Engineering Journal, 42, 148-152.

Niharika, A.; Aquicio, J.M.; Anand, A. 2010. Antifungal properties of neem (Azardirachta indica) leaves extract to treat hair and dandruff, $E$ International Scientific Research Journal, 2(3), 244-252.
Prabhamanju, M.; Shankar, S.G.; Babu, K.; Ranjith, M.S. 2009. Herbal vs chemical substances as antidandruff ingredients : which are more in effective the management of dandruff ?-An overview, Egyptian Dermatology Online Journal, 5(2): 8

Rachmawati, I. 2014. Pengaruh konsentrasi ekstrak etanol daun seledri (Apium graveolens) terhadap hambatan pertumbuhan Candida albicans in vitro, Skripsi, Universitas Muhammadiyah Surakarta

Sudarsono; Pudjoanto, A.; Gunawan, D.; Wahyuono, S.; Donatus, I. A.; Drajad, M.; Wibowo, S.; Ngatidjan. 1996. Tumbuhan Obat, Hasil Penelitian, Sifat-sifat dan Penggunaan, Pusat Penelitian Obat Tradisional, UGM, Yogyakarta

Sukandar, E. Y.; Suwendar; Ekawati, E. 2006. Aktivitas ekstrak etanol herba seledri (Apium graveolens) dan daun urang aring (Eclipta prostate L.) terhadap Pytirosporum ovale, Majalah Farmasi Indonesia, 17(1), 712.

van Wassenhove, F.; Dirinck, P.; Vulsteke, G.; Schamp, N. 1990, Aromatic volatile composition of celery and celeriac cultivars, Hort Science, 25(5), 556-559. 